\section{A Rapid Method for Preparing DNA from Blood, Suited for PCR Screening of Transgenes in Mice}

\author{
Gösta Winberg \\ Department of Tumor Biology, \\ Karolinska Institutet, S 10401 \\ Stockholm, Sweden
}

A procedure for the rapid preparation of DNA from whole blood of mice is described. Hemoglobin is removed from the blood by selective lysis of erythrocytes, followed by the release and denaturation of DNA from the leukocytes by boiling in a suspension of Chelex-100. The supernate is added directly to the PCR. A volume of $50-200 \mu \mathrm{l}$ of blood is required. The method allows sample preparation in 1 hr.

\section{RESULTS AND DISCUSSION}

The screening of transgenic mice, particularly the back-crossing of the transgenes from a hybrid founder into an inbred background, is laborious. Rapid screening of the transgene is also of crucial importance for allowing rapid breeding without incurring high costs for keeping untested litters. The use of the PCR instead of Southern blot analysis simplifies the detection of specific sequences, but sample preparation can often take a day or two, especially when several litters have to be analyzed.

The standard procedure involves the extraction of DNA from the mouse tail using established DNA extraction techniques, ${ }^{(1)}$ yielding DNA of high purity that is suitable for restriction enzyme cleavage. It has been realized, however, that PCR reactions do not require high-purity DNA, and thus abbreviated protocols have been devised that produce DNA of lower purity but allow a more convenient sample preparation. In such protocols, tail tips are lysed directly with SDS and the released DNA is deproteinized overnight with proteinase $\mathrm{K}$. Phenol and chloroform extractions are omitted, and nucleic acids are precipitated with isopropanol. ${ }^{(2)}$

Although blood is a convenient source of cellular material, its use for DNA preparation is associated with two technical problems. First, only $0.1 \%$ of the blood cells are nucleated leukocytes. The remaining $99.9 \%$ are erythrocytes, which contribute a large amount of protein to the preparation. In addition, the iron released from hemoglobin may damage DNA during heating in subsequent PCR cycles, resulting in weak PCR signals. ${ }^{(3)}$

Several procedures for extracting DNA from blood have been de- scribed. ${ }^{(3-6)}$ In the most rigorous protocols, buffy coat lymphocytes are first isolated and DNA is extracted using one or several steps involving detergent lysis, protease treatment, high salt precipitation of residual protein, and ethanol or isopropanol precipitation of the nucleic acids. ${ }^{(6)}$ One simplification of these procedures is using whole blood, reducing the time for SDS-lysis and deproteinization and omitting precipitation of the DNA before its use in PCR. ${ }^{(4)}$ A yet simpler procedure requires only boiling 1-3 $\mu \mathrm{l}$ of whole blood in $50 \mu \mathrm{l}$ of water before adding $39 \mu \mathrm{l}$ of the lysate to the PCR reaction. ${ }^{(7)}$ These simplified procedures $^{(4,7)}$ rely on using very small amounts of whole blood to avoid the aforementioned problems. If SDS is used for lysing the blood, ${ }^{(4)}$ care must be taken to limit its final concentration in the PCR, since $0.01 \%$ SDS already inhibits Taq polymerase by $90 \%$. $^{(8)}$ If whole blood is simply lysed by boiling, the 1-3 $\mu$ l suggested in the published procedure ${ }^{(7)}$ actually represents the upper limit at which the PCR works. Using such lysates from $10 \mu \mathrm{l}$ of blood results in no visible signals (data not shown).

The present method was designed to allow not only the detection of transgenes in adult mice, which have about 10,000 leukocytes per microliter of blood,(9) but also from fetuses, which have about $1000 / \mu 1$, and from mice used in bone marrow transplant experiments, where low cell counts and chimeric animals may be a problem. Like the previous quick procedures, ${ }^{(4,7)}$ sample preparation takes about $1 \mathrm{hr}$, and the results can be obtained the same day the samples are collected. Unlike previous methods (except ref. 7), our method does not use any detergents or proteases. It relies on the differential sensitivity of erythrocytes and leukocytes to lysis in a specific ionic environment (see below). Most of the hemoglobin is removed by dilution in the specific lysis buffer, and iron released from residual hemoglobin is chelated using Chelex-100, which results in improved PCR signals as described. ${ }^{(3)}$ The technique allows screening of several litters of mice in 1 day, using one to two drops of blood as the source for DNA. It was worked out while back-crossing 
mice from C57BL $\times$ DBA founders into a C57BL inbred background. The transgene was, in this case, the EBV BNLF1 membrane protein $^{(10)}$ under the control of the HSV-1 thymidine kinase promoter.

Blood was collected either from the tail vein or by retrobulbar bleeding. One to two drops of blood were directly collected in 15-ml conical Falcon tubes containing $10 \mathrm{ml}$ of $155 \mathrm{~mm}$ $\mathrm{NH}_{4} \mathrm{Cl}, 10 \mathrm{~mm} \mathrm{KHCO}_{3}$, and $0.1 \mathrm{~mm}$ EDTA-Na 2 (pH 7.4). The contents were mixed by inversion and the tubes left for 5-10 min at room temperature to allow selective lysis of the erythrocytes. The nucleated blood cells were pelleted at $1500 \mathrm{rpm}$ in a Sorvall RT6000 centrifuge for $10 \mathrm{~min}$. After decanting the supernate, a pellet of white blood cells could be observed in the bottom of the tube. After standing the tubes upright briefly, most of the remaining erythrocyte ghosts could be removed with a 1-ml micropipet without disturbing the white cell pellet (optionally, the lysis step could be repeated once). The white cell pellet was resuspended in $1 \mathrm{ml}$ of phosphatebuffered saline (PBS), transferred to a 1.5- $\mathrm{ml}$ microcentrifuge tube, and sedimented for $1 \mathrm{~min}$ at $5000 \mathrm{rpm}$ in an Eppendorf centrifuge. The supernate was again decanted gently; buffer remaining at the lip was blotted off on tissue paper, and the cell pellet was suspended by vortexing in the $10-20$ $\mu \mathrm{l}$ of PBS remaining in the tube. With a 1-ml micropipet, $200 \mu \mathrm{l}$ of a $50 \%$ suspension in water of Chelex-100 (400 minus mesh, Bio-Rad, Richmond, CA) was quickly added to the tube and mixed with the cells. The cells were then lysed in the Chelex suspension by boiling for 1-2 $\min .^{(3)}$ The tubes were chilled on ice, and the Chelex was pelleted for $30 \mathrm{sec}$ at $14,000 \mathrm{rpm}$. For a $100-\mu \mathrm{l} \mathrm{PCR}$ reaction, $10 \mu \mathrm{l}$ of the supernate was used. This corresponds to about $10 \mu \mathrm{l}$ of whole blood per PCR reaction. It was important to use the 400 minus mesh of Chelex-100. Attempts to use 100-200 mesh Chelex as previously recommended ${ }^{(3)}$ often resulted in contamination of the micropipets, since the bead size is close to the size of the orifice of the pipet tip, causing occasional blockage followed by sudden release of liquid into the tip. The method was successfully used with as little as $50 \mu$ l of blood for the reagent volumes indicated. The Chelex lysate can be used for PCR only for 2-3 days if kept at $4^{\circ} \mathrm{C}$. Tails were collected and frozen at $-70^{\circ} \mathrm{C}$ as starting material for high-quality DNA preparations, should more detailed information about the structure of the transgene be subsequently required.

Figure 1 shows the results of a simultaneous screening of four litters (a total of 32 mice) from different LMP1 transgenic founders. The founders carried one to two copies of the transgene. Although two or three samples are difficult to interpret due to a weak signal, the distinction between positive and negative was generally sufficiently clear to permit continuted breeding and elimination of negative mice from the litters.

\section{ACKNOWLEDGMENTS}

The author wishes to thank Prof. F.
Wiener for valuable advice and the Cancer Research Institute (CRI), Concern Foundation, for personal support. This study was supported by the Swedish Cancer Society, the CRI, Concern Foundation, and by PHS grant 2RO1 CA30264-10 awarded by the National Cancer Institute, DHHS.

\section{REFERENCES}

1. Sambrook, J., E.F. Fritsch, and T. Maniatis. 1989. Molecular cloning, 2nd edition. Cold Spring Harbor Laboratory Press, Cold Spring Harbor, New York.

2. Abbott, C., S. Povey, N. Vivian, and R. Lovell-Badge. 1988. PCR as a rapid screening method for transgenic mice. Trends Genet. 4: 325.

3. Singer-Sam, J., R. Tanguay, and A.D. Riggs. 1989. Use of Chelex to improve the PCR signal from a small number of cells. Amplifications 3: 11.

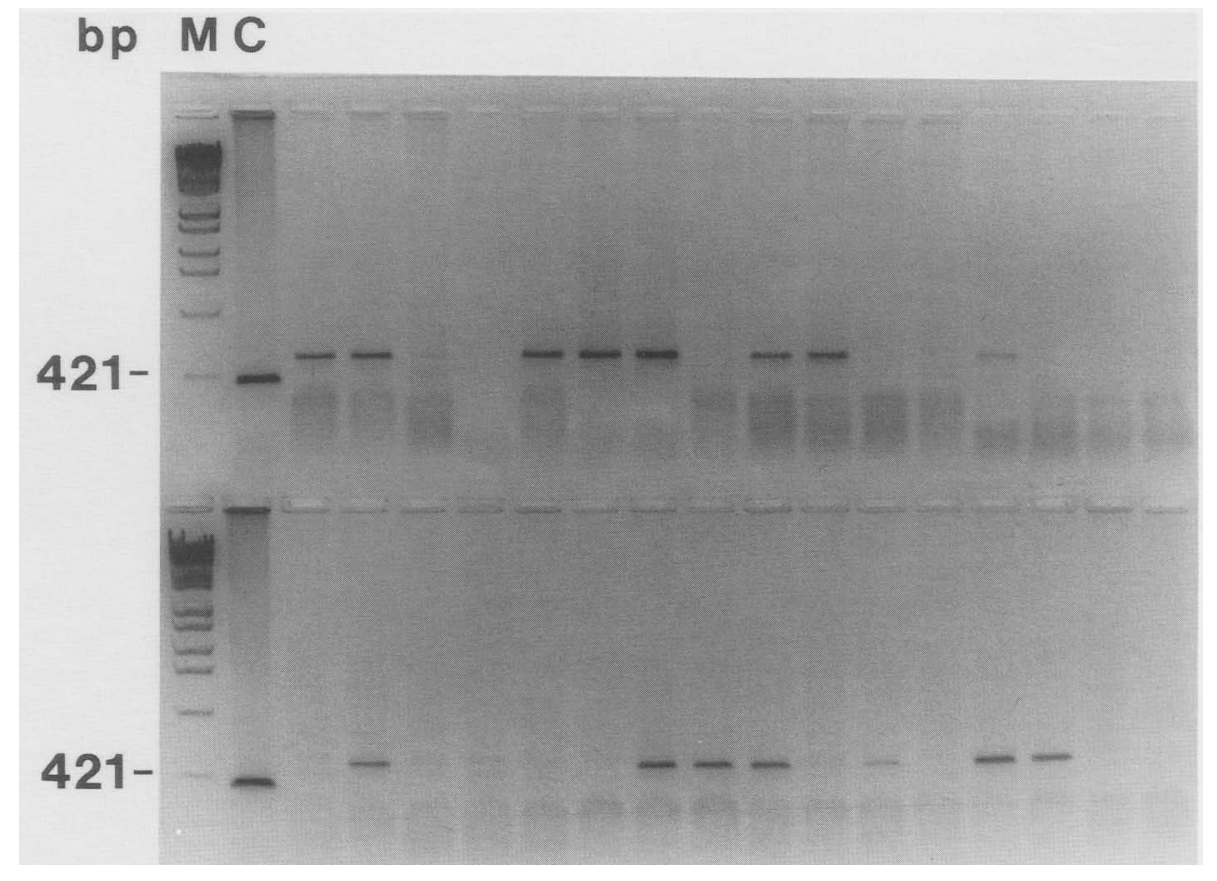

FICURE 1 Screening of 32 mice from four back-cross litters of LMP1 transgenic C57BL $\times$ DBA founders into C57BL. Each PCR reaction contained $10 \mu$ l of DNA, prepared as described, 69.5 $\mu \mathrm{l}$ of $\mathrm{H}_{2} \mathrm{O}, 10 \mu \mathrm{l}$ of $10 \mathrm{x}$ PCR buffer $(500 \mathrm{mM} \mathrm{KCl}, 200 \mathrm{mM}$ Tris- $\mathrm{HCl}, \mathrm{pH} 8.5,0.01 \%$ gelatin, 20 $\mathrm{mM} \mathrm{MgCl}_{2}$ ), $8 \mu \mathrm{l}$ of dNTP mix ( $2.5 \mathrm{mM}$ of each dNTP), $1 \mu \mathrm{l}$ each of the two primers (at 100 $\mu \mathrm{M}$ ), and 2.5 units of Taq DNA polymerase (Cetus, $8 \mathrm{U} / \mu \mathrm{l}$ ). The PCR was run for 25 cycles with $30 \mathrm{sec}$ at $94^{\circ} \mathrm{C}, 120 \mathrm{sec}$ at $60^{\circ} \mathrm{C}$, and $60 \mathrm{sec}$ at $72^{\circ} \mathrm{C}$. Ramps times were about $60 \mathrm{sec}$ each. The primers were 24 bases long with their $3^{\prime}$ ends at EBV coordinates 169,456 and 168,949 , respectively. ${ }^{(10)}$ The figure shows a negative of an ethidium bromide-stained $1 \%$ agarose gel. (M) Marker; lambda clts857,Sam7 cleaved with StyI. (C) Positive control DNA. One microgram of DNA from a cell line carrying a cDNA copy of the LMP1 gene. The expected fragment size for the cDNA fragment is $402 \mathrm{bp}$, whereas the transgene, containing the two introns in the LMP1 gene, produces a 556-bp fragment. The closest marker fragment is $421 \mathrm{bp}$. 


\section{Technical TipsIIIIII}

4. Chen, S. and G.A. Evans. 1990. A simple screening method for transgenic mice using the polymerase chain reaction. Biotechniques 8: 32-33.

5. Higuchi, R. 1989. Rapid, efficient DNA extraction for PCR from cells or blood. Amplifications 2: 1-3.

6. Miller, S.A., D.D. Dykes, and H.F. Polesky. 1988. A simple salting out procedure for extracting DNA from human nucleated cells. Nucleic Acids Res. 16: 1215.

7. Skalnik, D.G. and S. Orkin. 1990. A rapid method for characterizing transgenic mice. Biotechniques 8: 34 .

8. Gelfand, D.H. 1989. thermus aquaticus DNA polymerase. In Polymerase chain reaction (eds. H.A. Ehrlich, R. Gibbs, and H.H. Kazazian, Jr.), pp. 11-17. Cold Spring Harbor Laboratory Press, Cold Spring Harbor, New York.

9. Pugh, R. 1968. The mouse, pp. 272-273. Burgess Publishing Company.

10. Baer, R., A.T. Bankier, M.D. Biggin, P.L. Deininger, P.J. Farrell, T.J. Gibson, G. Hatfull, G.S. Hudson, S.C. Satchwell, C. Seguin, P.S. Tufnell, and B.G. Barrell. 1984. DNA sequence and expression of the B95-8 Epstein-Barr virus genome. Nature 310: 207-211.

Received April 30, 1991; accepted in revised form June 18, 1991. 


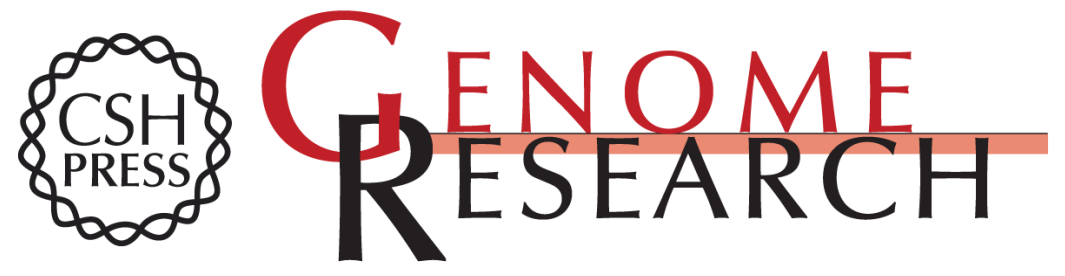

\section{A rapid method for preparing DNA from blood, suited for PCR screening of transgenes in mice.}

G Winberg

Genome Res. 1991 1: 72-74

Access the most recent version at doi:10.1101/gr.1.1.72

\section{License}

Email Alerting

Receive free email alerts when new articles cite this article - sign up in the box at the Service top right corner of the article or click here.

\section{Affordable, Accurate Sequencing.}

